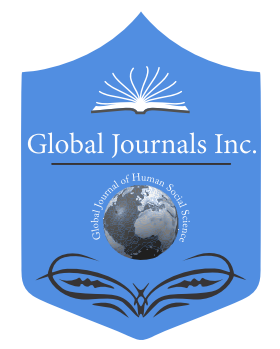

\title{
Two Models to Improve Undergraduate Writing Perception and Capabilities in Plant and Soil Sciences
}

By Speth, C., D. Lee, H. Blanco-Canqui \& S. J. Ruis

Abstract- Integration of professional writing with peer and instructor feedback as a graded component can be a strategy for writing improvement in an applied science undergraduate curriculum. The objective of this study was to assess the benefit of professional writing in first and second-year undergraduate courses in Agronomy and Horticulture with two different models for the writing experience. In the first-year course, students communicated the results of two plant growth experiments in the format of a standard research article. In the second-year course, students wrote a group report as a review of published research or a research-based proposal to address a soil management issue. Students were surveyed to determine their major and learning style evaluated with an 18-question assessment. Students also chose their level of agreement with seven statements about the process and importance of professional scientific writing at the beginning and then at the end of the semester. Survey results showed that confidence in using and creating professional writing increased among students for both courses. Students in the first-year course showed a greater understanding of the value of peer reviewed research.

Keywords: undergraduate, writing perception, writing capabilities, plant science, soil science.

GJHSS-G Classification: FOR Code: 130399

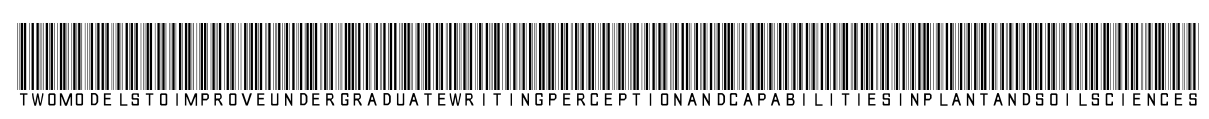

Strictly as per the compliance and regulations of:

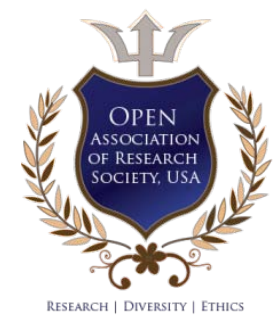

(c) 2021. Speth, C., D. Lee, H. Blanco-Canqui \& S. J. Ruis. This is a research/review paper, distributed under the terms of the Creative Commons Attribution-Noncommercial 3.0 Unported License http://creativecommons.org/licenses/by-nc/3.0/), permitting all non-commercial use, distribution, and reproduction in any medium, provided the original work is properly cited. 


\title{
Two Models to Improve Undergraduate Writing Perception and Capabilities in Plant and Soil Sciences
}

\author{
Speth, C. ${ }^{\alpha}$, D. Lee ${ }^{\sigma}$, H. Blanco-Canqui ${ }^{\rho}$ \& S.J. Ruis ${ }^{\omega}$
}

\begin{abstract}
Integration of professional writing with peer and instructor feedback as a graded component can be a strategy for writing improvement in an applied science undergraduate curriculum. The objective of this study was to assess the benefit of professional writing in first and second-year undergraduate courses in Agronomy and Horticulture with two different models for the writing experience. In the first-year course, students communicated the results of two plant growth experiments in the format of a standard research article. In the second-year course, students wrote a group report as a review of published research or a research-based proposal to address a soil management issue. Students were surveyed to determine their major and learning style evaluated with an 18-question assessment. Students also chose their level of agreement with seven statements about the process and importance of professional scientific writing at the beginning and then at the end of the semester. Survey results showed that confidence in using and creating professional writing increased among students for both courses. Students in the first-year course showed a greater understanding of the value of peer reviewed research. The variety of professional writing choices that engaged the second-year course students provided them with a different opinion for the strictness of scientific writing than the first-year students. Students in this study varied in their approaches to learning. Overall, professional writing benefited students in their learning experience but assessing the differences in approach among students is important to account for differences in responses to the professional writing projects.
\end{abstract}

Keywords: undergraduate, writing perception, writing capabilities, plant science, soil science.

\section{INTRODUCTION}

T he courses and expectations for an applied science major in agriculture such as Agronomy and Horticulture, are designed to prepare students for the professional workforce by teaching them to solve plant and soil system problems. To culminate the student's academic program, many universities require fourth-year students to complete a capstone course which integrates what they have learned throughout their academic career. The learning outcome for the capstone course at the University of Nebraska-Lincoln is for students to generate a creative or scholarly product that requires them to apply broad knowledge, appropriate technical proficiency, information collection,

Author $\sigma$ : Dept. Agronomy and Horticulture, University of NebraskaLincoln, 1875 N. $38^{\text {th }}$ St., Lincoln, NE 68583.

e-mail:dlee1@unl.edu synthesis, interpretation, presentation, and reflection. A recent review of the University of Nebraska-Lincoln's Department of Agronomy and Horticulture's capstone courses showed that instructors rated scientific writing as the weakest skill among their students. Thus, curriculum improvement by expanding the students' experience with scientific writing was a priority targeted by the Department. Specifically, faculty who teach first through third year courses in the Department were encouraged to include professional writing into graded work. Furthermore, the scientific writing assignments should include review by the instructors and students and the students given enough time to improve their written projects before submission. This strategy is intended to improve student confidence and appreciation of writing to promote and advance their understanding of plant and soil science applications in the real world.

Some of the strategies to incorporate professional writing into an applied science course include emails, publications or reports, and others. Regardless of the strategy, professional writing is expected to synthesize and integrate concepts using reliable information applied to specific situations (Motavalli et al., 2003). A comparison of the relative impact of written communication courses, writing centers, and repeated practice with science writing in biology and ecology courses showed that only repeated writing had a measured impact on writing effectiveness (Jerde and Taper, 2004). Furthermore, student-written reports on experiments conducted during the course and research article reviews can improve critical thinking capabilities (Brillhart and Debes, 1981; Krest and Carle, 1999). Holyoak (1998) presented a model for writing across a biology curriculum with the writing designed to build professional expertise. Writing with feedback to promote improvement was the most impactful method to improve student exam performance in a biology course (Moore, 1993). Thus, the incorporation of professional writing across an applied plant and soil science curriculum would be expected to increase student's confidence in their ability to use and create writing and focuses learning toward the application of plant and soil science concepts.

A study on the impact of writing in a secondyear undergraduate soil management course 
demonstrated the contribution of writing on student learning (Blanco-Canqui et al., 2019). For example, about $55 \%$ of students indicated they learned more by writing than from readings and lectures. They also found peer review by classmates and instructor feedback helpful. This soil management course serves a variety of majors and responses among majors did not generally differ. However, students in applied plant and soil science programs may differ in learning styles in addition to major (Schmeck, 1988; Speth et al, 2006; Speth et al, 2007). Biggs (1993), observed important connections between the way students view learning or studying and how they approach writing tasks. Researchers dedicated to understanding student learning styles have developed the Approaches and Study Skills Inventory (Entwistle and Ramsden, 1983) with thousands of university students participating in large-scale quantitative studies using these questionnaires. These questionnaires show students tend to use one of three learning approaches: Surface, Strategic, or Deep. The approaches are related to how much satisfaction students experience in their learning. Students with a deep approach report higher quality learning outcomes, more enjoyment, and better grades. Students with surface approaches are less satisfied with their learning and generally have poorer grades (Ramsden, 1992). Each approach has a characteristic type of motivation, ranging from interest to getting good grades, or trying not to fail. Each has a characteristic intention, which might be to understand the material and be able to apply it or to memorize it for the test. Finally, each approach is characterized by either organized or disorganized study methods. Understanding how students with varied approaches work on their current writing projects can guide the development of future writing assignments and how those assignments are integrated into courses.

The purpose of this study was to evaluate changes in skills, confidence, and awareness of the value of peer-reviewed scientific writing in response to two writing experiences integrated into first- and second-year courses in an applied plant science curriculum. The hypotheses for this evaluation study were:

1. Students (in both classes) will gain confidence in their science writing ability.

2. The type of professional writing assignment will influence the specific improvement students report in using and creating professional writing.

3. Gains in confidence will depend on the approach or learning style of the student.

\section{il. Materials and Methods}

a) Writing Assignments and Participants

This exploratory study was conducted in the classroom environment, not as a controlled experiment.
Two styles of assignments were assigned, one in each of two undergraduate courses in the Department of Agronomy \& Horticulture at the University of NebraskaLincoln. The two writing assignments were authentic applications of professional writing linked to learning goals in each course. Students in AGRO 131 Plant Science, the introductory plant biology course, wrote a scientific research article to communicate the results of two hypothesis-driven experiments conducted in the course. Students worked in groups on the experiments and did their writing individually. Students in AGRO 269 Principles of Soil Management wrote a term paper in groups, showing competency in finding and summarizing peer-reviewed articles and their applications to soil management problems.

The timeline for completion of various stages of the writing assignment into the first year and second year courses is shown in Figure 1. In the Plant Science class, student group experiments are planned and started in the first two weeks and completed by week 4 . Instruction on the scientific method, research article organization, and purpose of each component of the article is integrated into course lectures, quizzes, and exams. Students get a rubric-based grade of their draft and can submit a final draft where they can improve their writing and grade based on "peer review." This is repeated for experiment two. The two experiment write ups constitute ten percent of the course grade. Teaching assistants and the instructor schedule office hours to provide individual writing assistance to students.

In the Soil Management class students wrote a term paper in groups of two or three revolving around one of two soil management ideas: 1) a literature review of a soil management practice or 2) propose a plan to solve a soil problem. Both types of papers required students to review scientific literature including peerreviewed articles, extension articles, class readings, and class lectures. Students were required to include at least 15 references, at least five of which needed to be peer reviewed journal articles, three tables or figures, and write an eight to ten pages long single-spaced document. Further details on the layout of each type of paper are described in Blanco-Canqui et al. (2019). To facilitate student preparation and completion of the term paper, students were assigned groups the fourth week of class, submitted an outline the sixth week of class, submitted the first draft for review three weeks before the end of semester, and submitted the paper the last week of class. Students reviewed each other's paper outlines and first draft in addition to both being reviewed by the instructor and teaching assistant.

All enrolled students in the Plant Science course in the fall semester of 2016 were invited to participate in an evaluation of the experiment write-up assignments. Those who gave their informed consent to participate in 
the pre- and post-assessments included 71 first-year, five second-year and one fourth-year students. All enrolled students in the Principles of Soil Management course in the fall semester of 2017 were invited to participate in an evaluation of the group term paper assignment. Those who gave their informed consent to participate in the pre- and post-assessment included 17 second-year, 26 third-year, 13 fourth-year students and one additional student who chose the "other" answer.

\section{b) Grouping by Major}

Approximately half the students in the Plant Science sample also took the Soil Management course a year later, but it was not possible to match them and do a within student analysis across years. The instructors had chosen two different kinds of identification systems to meet their own evaluation needs. Students were grouped based on majors. The first-year Plant Science course included 14 different majors, the most numerous being 15 Agronomy majors plus one Soil Science and one Horticulture major, 15 Agricultural Business or Economics majors, and 27 Integrated Science majors. This provided three student groups based on major. The same three groupings were used in the second-year Soil Management course. This course included 11 different majors, the most numerous being 33 Agronomy majors plus three Soil Science and one Horticulture major, six Agricultural Business or Economics majors, and seven of the Integrated Science majors. Both groups answered evaluation questions specific to their course and their writing assignment.

\section{c) Grouping by approach}

An assessment of learning style, as defined by the approaches to learning and studying (ASSIST), was included to answer questions about how students with different needs, motives, learning skills or attitudes would respond to different kinds of writing assignments. The 18-item Approaches and Study Skills Inventory for Students or ASSIST was administered to understand students' attitudes toward their self-directed learning or studying activities. The ASSIST has six items about each of the three primary approaches to self-directed learning or studying. Deep, Strategic or Surface describe these three approaches.

At the beginning of the semester, students who chose to participate in the evaluation study answered the 18 items on the ASSIST. There is also a long form of the ASSIST (Tait et al., 1998), that includes two questions that show important beliefs and attitudes that affect students' experience of education: What is your definition of learning? And, what motivates you to study and learn? These two questions were included. The questions and scoring guide for the short and long forms of the ASSIST is currently available at: http:// www.research.ed.ac.uk/portal/en/persons/noel-entwistle (79568f91-5cc9-4473-a0de-ed6c3c88d464)/ publications.html
Individual students responded to each ASSIST question by how much they agree or disagree on a fivepoint Likert scale from $1=$ strongly disagree to $5=$ strongly agree. These are treated as a continuum so that $3=$ Unsure or undecided. Responses to the six items on the Surface, Strategic and Deep Scales were added together into scale scores. Every student had a score for the Deep, Strategic and Surface approaches. These scale scores were then converted into Standard scores.

Standard scores are commonly used for various purposes in the field of educational measurement. The $Z$ score, one type of standard score, enabled us to compare two scores that are from different normal distributions, to see which score is more extreme. The $Z$ scores are expressed in terms of the number of standard deviations above or below the mean of all the scores. The formula for determining a student's standard $(Z)$ score on each of the three scales (Deep Strategic, and Surface) is: $Z=(X$, which is an individual's total score on a six-item scale on the ASSIST, minus the mean of all scores on that scale) divided by the standard deviation for all scores on that scale. (Allen and Yen, 1979).

The highest of the three $Z$ scores for each student determined what Approach group ("Deep," "Strategic" or "Surface") they were assigned. That was operationalized by creating a new variable (column on the data file), "Approach," and typing Deep, Strategic or Surface on the row in the data file representing each individual. This scoring method was described at length by Speth, Lee and Hain (2006). It is important to recognize that no student is treated any differently based on this categorization. Indeed, it is not until after the course ended that the instructors were told how many of each group they had in their course. This analysis allowed for end-of-course responses to be interpreted in terms of how students with similar answers to the ASSIST questions reacted to different instructional methods.

We also asked the students seven questions using a five-point Likert scale from $1=$ strongly disagree to $5=$ strongly agree. These were treated as a continuum so that $3=$ Unsure or undecided.

- "I have had experience writing scientific reports in class."

- "I am confident that I can write an original science report based on an experiment I have conducted."

- "I enjoy the process of planning and conducting a scientific experiment designed to test a hypothesis."

- "It is not important to follow strict and standard rules in writing a scientific report to communicate a scientific discovery between scientists.

- "I am not familiar with how to find and write a peerreviewed scientific report." 
- "The writing and sharing of peer-reviewed and published scientific reports is less important now than it was decades ago."

- "I understand the value that peer-reviewed and published scientific reports have in society.

d) Statistical analysis

The data file from each class was submitted to analysis using IBM SPSS Statistics Version 23. To reveal statistically significant differences among groups with unequal treatment groups, Analyses of Variance used Compare Means: Means, selecting the Anova Table and Eta option. Comparison of pre-assessment to postassessment results for variables was completed with Compare Means: Paired Samples T-Tests.

\section{ili. Results}

a) Changes between pre- and post-assessments

In the Plant Science course, differences between the class means on the pre- and postassessment were statistically significant at the 0.05 level on five of the seven evaluation items (Table 1). In the Plant Science course, students reported an increase in experience (49\%), confidence (33\%) and enjoyment $(14 \%)$ in science writing after their two-research article writing assignments (Table 1, items 1, 2, 3). The Plant Science students also reported a $38 \%$ reduction in unfamiliarity with writing and finding peer reviewed articles and a $14 \%$ increase in the value of this published writing to society (items 5,7 ).

In the Soil Management course, differences between class means on the pre- and postassessments were statistically significant at the 0.05 level on four of the seven evaluation items (Table 1). The Soil Management students reported a increase in experience (15\%) and confidence (11\%) in writing after they had written their outlines or reviews (Table 1, items $1,2)$. They did not report a significant change in their enjoyment of planning and conducting research (Table 1, item 3). Their literature review combined with creating a professional report structured to appeal to an applied audience appeared to influence their response to the statement that "strict and standard rules in writing are important to communicate a scientific discovery between scientists" (Table 1, item 4). Soil management students had a 29\% reduction in their agreement with this statement after experiencing a range of professional writing formats in their soil management literature review.

\section{b) Learning Style or Approach Differences}

Students in our applied science majors vary in their approaches to learning. Table 2 shows the distribution of approaches by major in these two courses. A higher proportion of surface learners were enrolled in the Plant Science course than the Soil Management course. By contrast, a greater proportion of strategic and deep learners were enrolled in the Soil Management course than the Plant Science course.

Analysis of the students as approach groups provided additional insights on the response of students to professional writing experiences. The seven questions posed in the pre and post surveys showed some impacts that were approach specific and some that impacted all students. Agreement with the statement, "I have experience in science writing in class" increased from pre to post surveys in both classes and was not approach specific (Tables 1, 2). In contrast, there were some significant differences among approach groups in their response to the writing assignment work (Fig. 2-4).

Figure 2 shows that surface learners in both courses differed in their response to the statement "I enjoy the process of planning and conducting a scientific experiment". In the Plant Science course, surface learners rated this question $36 \%$ lower than strategic and deep learners in the pre-survey but not the post survey after the students had conducted and written scientific style reports on two experiments. In the Soil Management course, the surface group rated this statement lower than strategic and deep learners in both the pre and post survey following writing the group term paper.

The students in the Plant Science course did not change in their response to "writing and sharing peer-reviewed and published scientific reports is less important now" between the pre and post surveys (Table 1). However, there was a persistent difference among approach groups. The deep learners rated this statement 34\% lower than the strategic and surface learners in both the pre and post survey (Figure 3). The deep learners' disagreement with this statement implies they see the scientific process as an ongoing progression. In contrast, the writing experience for the Soil Management course appears to remove the significant difference observed in the Strategic learner group in the pre-survey compared to post-survey (Figure 3).

A similar effect was observed with the student response to the statement, "I understand the value that peer-reviewed and published scientific reports have in society" (Figure 4). In both the Plant Science and the Soil Management course, surface learners had a lower agreement with this statement.

\section{Discussion}

The results provided insights on our three hypotheses.

1. Students (in both classes) will gain confidence in their science writing ability.

Results demonstrate that integration of writing assignments that have a relevant context for students can advance their confidence in science writing and appreciation for the scientific process. The professional writing students conducted in both courses increased 
experience and confidence in professional writing. Results are also consistent with those observed in biological science programs which have systematically tested or integrated professional writing in their curricula (Brillhart and Debes, 1981; Krest and Carle, 1999; Moore 1993, 1994).

2. The type of professional writing assignment will influence the specific improvement students report in using and creating professional writing.

Results indicate that the type of professional writing assignment influenced specific improvements in student perception and confidence. The Plant Science students reported significant gains in their agreement with the statement that they "enjoy the process of planning and conducting a scientific experiment designed to test a hypothesis" (Table 1). This was not observed with the Soil Management students, who did not actually conduct an experiment. The Soil Management class writing assignment was focused on a survey of published research targeting a soil management problem and not literature related to a single experiment. The specific gains in confidence measured here are consistent with the approach advocated in previous work (Holyoak, 1998).

The value of combining the work of conducting an experiment, then writing like a scientist to share those results was reflected in student comments from the Plant Science course.

"It was quite a bit of work and took time to write it up. The experiment was quick and easy but the write up was hard due to the fact that you had to think like a scientist." (Student classified as primarily a Surface learner based on ASSIST scale scores.)

"The experiment write-up was challenging, as it was my first time writing a scientific paper." (Student classified as primarily a Surface learner based on ASSIST scale scores.)

"It was helpful, it taught me how to report any kind of scientific experiment which is important. It also taught me how to search for reliable scientific information and how to include reference in my writings." (Student classified as primarily a Strategic learner based on ASSIST scale scores).

"The experiment was awesome. I started by getting few marks but by the end I became familiar with the procedures and I got much marks. This gave me some courageous of knowing more about scientific writings, not only to be limited on the experiment but also on other researches." (Student classified as primarily a Deep learner based on ASSIST scale scores).

The impact of writing assignment specificity was likewise observed in the changes for the 200-level soils class students. Statement 4 "It is not important to follow strict and standard rules in writing a scientific report" was based upon the expectation in the Plant Science course for students to experience writing in a very strict and predictable style. They were expected to find one peer reviewed research article that they could cite in their writing, but they were only expected to evaluate this article by the title and abstract. Thus, they did not change significantly in their opinion on the importance of strict writing standards.

In contrast, Soil Management students had a very different professional experience in finding and reviewing published reports for their writing assignment. The review article or proposal writing for the Soil Management students required a review of the published research with a higher expectation for comprehension. Students in the Soil Management course needed to review and cite at least five peerreviewed journal articles to support conclusions and recommendations. Students were given a tutorial on how to find such articles and were to use the findings and tables or figures to support the discussion or why a specific management practice should be included. The students were then expected to organize their report or management plan based on the needs or interests of a specific professional audience. This would be consistent with recognizing that a range in organization approaches can be found in peer-reviewed scientific publications. This progression in the professional application of professional writing from the 100-level Plant Science class to the 200-level Soil Management course is advocated in studies which emphasized writing as a tool for advancing science understanding (Krest and Carle, 1999; Moore 1993, 1994).

Both courses incorporated a review process by peers and instructors. Therefore, these writing assignments provided students the opportunity to improve their writing by responding to the peer or instructor review (Figure 1). This added rigor also adds to the instructional cost to implement this graded work into a course.

3. Gains in confidence will depend on the approach or learning style of the student.

The impact of the writing assignment experience varied in some cases with the approach of the student. This was observed in the student agreement with "enjoying the process of conducting an experiment" where a majority of the Plant Science students in the Agronomy and Soils major were surface learners (Table 3 ). This group was significantly different from the Strategic and Deep approach students at the start of both courses (Figure 2). However, in the Plant Science course, where conducting experiments was part of the learning, difference in approach was not observed in the post survey scores. The surface learning approach difference persisted in the Soil Management class where students did not conduct an experiment (Figure 2). Ramsden (1992) noted that surface learners 
gain less enjoyment from their learning experience. This emphasizes the importance of connecting the professional writing with learning activities students enjoy because they have personal interest and are actively engaged.

Perhaps the most gratifying finding from this study was the impact of the scientific writing work on students whose highest scale score was on the Surface items. These students were significantly more likely to say they do not enjoy doing experiments on the preassessment. That difference was no longer significant on the post-assessment. One student whose highest scale score was on the Strategic Approach said: "It was both fun and educational. I had no idea how to do this, but with teacher's help I did it."

The results from this writing assignment impact assessment suggest that assignments such as conducting an experiment then writing in the scientific style have their biggest benefit on the students whose highest approach score was on the Surface scale. Given the relative abundance of the surface approach among the students entering our applied science program, the investment in resources toward this activity is warranted.

It is interesting to observe the learning approach difference in the Plant Science course response to the importance of peer-reviewed and published scientific reports (Figure 3). The Deep learners in this population were less likely to agree that science writing and publication was becoming less important and this difference was not changed by the writing assignment work. At the same time, coupling experimental or literature review research with writing helps all students. One student scoring highest on the Deep Approach Scale score wrote, "Starting my draft for the experiment write-up was difficult and I made many mistakes, but my final paper was easy, I enjoyed doing it because I already knew how to do it well."

These results support the instructional approach used in the Soil Management course, of creating diverse groups of students to work collaboratively to advance professional writing confidence in a group setting. This might not be popular as it takes students farther out of their comfort zones. This is an important outcome as most writing accomplishments our students will experience as professionals will require team collaboration with diverse groups of co-workers.

\section{Conclusions}

This study demonstrated the benefit of incorporating professional writing in the classroom through increased confidence reported by students in using and creating professional writing. Approach differences among the students impact their response to some of the aspects of learning through writing. A high proportion of surface learners are found among students served by our curriculum and the incorporation of writing work was particularly beneficial to students with this learning approach. Ideally, innovations will not just help students who are already successful, but make content learning accessible to students who need a little help to become the knowledgeable agronomists and horticulturalists needed to help feed a hungry world.

\section{References Références Referencias}

1. Allen, M.J. and Yen. W.M. (1979). Introduction to Measurement Theory. Brooks/Cole, Monterey, CA.

2. Biggs, J. (1993). What do inventories of students' learning processes really measure? A theoretical review and clarification. British Journal of Educational Psychology, 63: 3-19.

3. Blanco-Canqui, H., S. J. Ruis, C. Speth, and D. Lee. 2019. Integrating Writing into Undergraduate Soil Management Course Enhances Student Learning. Natural Sciences Education 48:190004

4. Brillhart, V. and Debs, M.B. (1981). Teaching writingA scientist's responsibility. Journal of College Science Teaching, 10(5): 303-304.

5. Entwistle, N., Ramsden, P. (1983). Understanding Student Learning. London: Croom Helm.

6. Holyoak, A.R. (1998). A plan for writing throughout (not just across) the biology curriculum. The American Biology Teacher, 60(3): 186-190.

7. Jerde, C.L. and Taper, M.L. (2004). Preparing undergraduates for professional writing: Evidence supporting the benefits of scientific writing within the biology curriculum. Journal of College Science Teaching, 33(7): 34-37.

8. Krest, M. and Carle, D.O. (1999). Teaching scientific writing: A model for integrating research, writing and critical thinking. The American Biology Teacher, 61(6): 223-227.

9. Leggette, H.R., Sitton, S. and Blackwell, C. (2011). Perceptions of agricultural industry recruiters on writing in the workplace. NACTA Journal, 55: 361-69.

10. Marton, F., Hounsell, D.J. and Entwistle, N.J. (Eds.) (1984). The experience of learning ( $2^{\text {nd }}$ ed.). Edinburgh: Scottish Academic Press.

11. Marton, F., and Saljo, R. (1976). On qualitative differences in learning: 1. Outcome and process. British Journal of Educational Psychology, 46, 4-11.

12. Moore, R. (1993). Does writing about science improve learning about science? Journal of College Science Teaching, 22(4): 212-217.

13. Motavalli, P.P., Patton, M.D., Logan, R.A. and Frey, C.J. (2003). Promoting environmental writing in undergraduate soil science programs. Journal of Natural Resources and Life Sciences Education, 32: 93-99. 
14. Ramsden, P. (1992). Learning to Teach in Higher Education. London: Routledge.

15. Schmeck, R.R., ed. (1988). Learning Strategies and Learning Styles: Perspectives on Individual Differences. New York: Plenum Press.

16. Speth, C.A., Lee, D.J. and Hain, P.M. (2006). Prioritizing improvements in Internet instruction based on learning styles and strategies. Journal of Natural Resources \& Life Science Education, 35: 35-41.

17. Speth, C.A., Namuth, D.M. and Lee, D.J. (2007). Using the ASSIST Short Form for evaluating an information technology application: Validity and reliability issues. Informing Science, 10: 107-119.

18. Tait, H., Entwistle, N. J., \& McCune, V. (1998). ASSIST: A reconceptualization of the Approaches to Studying Inventory. In C. Rust (Ed.), Improving student learning: improving students as learners (pp. 262-271). Oxford: Oxford Centre for Staff and Learning Development.

19. University of Southern California. "Why (smart) practice makes perfect." ScienceDaily. Science Daily, 13 July 2010. <https://www.sciencedaily. com/releases/2010/07/100712141855.htm>

Table 1: T-Test Results Comparing Pre to Post Assessment Means on the Seven Evaluation Items in Plant Science 131 and Soil Management 269: Paired Samples Statistics with Significance (2-tailed) ( $\mathrm{N}=61$ for Plant Science 131 and $\mathrm{N}=30$ for Soil Management 269)

\begin{tabular}{|c|c|c|c|c|}
\hline Assessment Item & $\begin{array}{c}\text { Plant } \\
\text { Science } \\
131\end{array}$ & $\begin{array}{c}\text { Mean } \\
\text { (Standard } \\
\text { Deviation) }\end{array}$ & $\begin{array}{l}\text { Soil } \\
\text { Management } \\
269\end{array}$ & $\begin{array}{l}\text { Mean } \\
\text { (Standard } \\
\text { Deviation) }\end{array}$ \\
\hline \multirow[t]{2}{*}{$\begin{array}{l}\text { 1. "I have had experience writing scientific } \\
\text { reports in class." }\end{array}$} & Pre- & $\begin{array}{c}3.10 \\
(1.160)\end{array}$ & Pre- & $\begin{array}{c}3.50 \\
(0.900)\end{array}$ \\
\hline & Post- & $\begin{array}{l}4.62^{\star} \\
(0.585)\end{array}$ & Post- & $\begin{array}{l}4.03^{\star} \\
(0.890)\end{array}$ \\
\hline \multirow{2}{*}{$\begin{array}{l}\text { 2. "I am confident that I can write an original } \\
\text { science report based on an experiment I } \\
\text { have conducted." }\end{array}$} & Pre- & $\begin{array}{c}3.44 \\
(0.975)\end{array}$ & Pre- & $\begin{array}{c}3.58 \\
(0.886)\end{array}$ \\
\hline & Post- & $\begin{array}{l}4.59^{*} \\
(0.559)\end{array}$ & Post- & $\begin{array}{l}4.00^{\star} \\
(0.966)\end{array}$ \\
\hline \multirow{2}{*}{$\begin{array}{l}\text { 3. "I enjoy the process of planning and } \\
\text { conducting a scientific experiment designed } \\
\text { to test a hypothesis." }\end{array}$} & Pre & $\begin{array}{c}3.75 \\
(0.925)\end{array}$ & Pre & $\begin{array}{c}3.52 \\
(1.061)\end{array}$ \\
\hline & Post & $\begin{array}{c}4.28^{*} \\
(0.859)\end{array}$ & Post & $\begin{array}{c}3.84 \\
(0.898)\end{array}$ \\
\hline \multirow{2}{*}{$\begin{array}{l}\text { 4. "It is not important to follow strict and } \\
\text { standard rules in writing a scientific report to } \\
\text { communicate a scientific discovery between } \\
\text { scientists." }\end{array}$} & Pre & $\begin{array}{c}2.36 \\
(1.096)\end{array}$ & Pre & $\begin{array}{c}1.87 \\
(0.885)\end{array}$ \\
\hline & Post & $\begin{array}{c}2.10 \\
(1.313)\end{array}$ & Post & $\begin{array}{l}2.42^{*} \\
(1.259)\end{array}$ \\
\hline \multirow[t]{2}{*}{$\begin{array}{l}\text { 5. "I am not familiar with how to find and write a } \\
\text { peer-reviewed scientific report." }\end{array}$} & Pre- & $\begin{array}{c}3.36 \\
(1.061)\end{array}$ & Pre- & $\begin{array}{c}2.87 \\
(1.176)\end{array}$ \\
\hline & Post- & $\begin{array}{c}2.05^{\star} \\
(1.056)\end{array}$ & Post- & $\begin{array}{l}2.23^{*} \\
(1.055)\end{array}$ \\
\hline \multirow{2}{*}{$\begin{array}{l}\text { 6. "The writing and sharing of peer-reviewed } \\
\text { and published scientific reports is less } \\
\text { important now than it was decades ago." }\end{array}$} & Pre- & $\begin{array}{c}2.20 \\
(0.813)\end{array}$ & Pre- & $\begin{array}{c}2.26 \\
(1.032)\end{array}$ \\
\hline & Post & $\begin{array}{l}1.95 \\
(.0902)\end{array}$ & Post & $\begin{array}{l}2.16 \\
(1.036)\end{array}$ \\
\hline \multirow{2}{*}{$\begin{array}{l}\text { 7. "I understand the value that peer-reviewed } \\
\text { and published scientific reports have in } \\
\text { society." }\end{array}$} & Pre & $\begin{array}{c}4.03 \\
(0.758)\end{array}$ & Pre & $\begin{array}{c}4.13 \\
(0.806)\end{array}$ \\
\hline & Post & $\begin{array}{c}4.60^{\star} \\
(0.588)\end{array}$ & Post & $\begin{array}{c}4.23 \\
(0.717)\end{array}$ \\
\hline
\end{tabular}

Table 2: Learning Style Approach category distribution among the major categories in Plant Science 131 and Soil Management 269.

\begin{tabular}{|c|c|c|c|c|c|c|}
\hline & \multicolumn{2}{|c|}{ Agronomy and Soil majors } & \multicolumn{2}{c|}{ Other majors } & \multicolumn{2}{c|}{ Integrated Science major } \\
\hline \multirow{2}{*}{ Approach } & $\begin{array}{c}\text { Plant } \\
\text { Science 131 }\end{array}$ & $\begin{array}{c}\text { Soil Management } \\
\mathbf{2 6 9}\end{array}$ & $\begin{array}{c}\text { Plant } \\
\text { Science 131 }\end{array}$ & $\begin{array}{c}\text { Soil Management } \\
269\end{array}$ & $\begin{array}{c}\text { Plant } \\
\text { Science 131 }\end{array}$ & $\begin{array}{c}\text { Soil Management } \\
269\end{array}$ \\
\hline Deep & $19.0 \%$ & $29.7 \%$ & $23.3 \%$ & $38.5 \%$ & $38.5 \%$ & $28.6 \%$ \\
\hline Strategic & $23.8 \%$ & $24.3 \%$ & $30.0 \%$ & $23.1 \%$ & $42.3 \%$ & $71.4 \%$ \\
\hline Surface & $52.4 \%$ & $45.9 \%$ & $43.3 \%$ & $38.5 \%$ & $15.4 \%$ & $0.0 \%$ \\
\hline Missing & $4.9 \%$ & $0 \%$ & $3.3 \%$ & $0 \%$ & $3.8 \%$ & $0 \%$ \\
\hline Total & $100 \%$ & $100 \%$ & $100 \%$ & $100 \%$ & $100 \%$ & $100 \%$ \\
\hline
\end{tabular}




\begin{tabular}{|c|c|c|c|c|c|c|}
\hline $\begin{array}{c}\text { AGRO } 269 \\
\text { Principles of } \\
\text { Soil Management }\end{array}$ & $\begin{array}{l}\text { Groups } \\
\text { Assigned }\end{array}$ & $\begin{array}{l}\text { Outline of } \\
\text { Review } \\
\text { or } \\
\text { Proposal }\end{array}$ & $\begin{array}{c}\text { Outline } \\
\text { Review } \\
\text { by Peers } \\
\text { and } \\
\text { Instructors }\end{array}$ & $\begin{array}{c}\text { Literature } \\
\text { Review } \\
\text { And } \\
\text { Group } \\
\text { Writing }\end{array}$ & $\begin{array}{c}\text { Draft } \\
\text { Submitted } \\
\text { For Peer } \\
\text { and Instructor } \\
\text { Review }\end{array}$ & $\begin{array}{c}\text { Final version } \\
\text { Group } \\
\text { Research Revie! }\end{array}$ \\
\hline
\end{tabular}

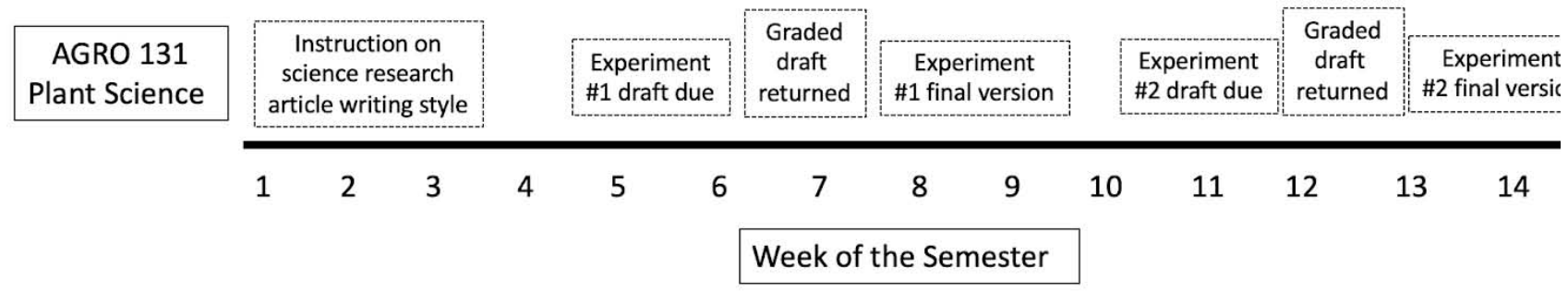

Figure 1: Writing Assignment, Review and Grading Timeline

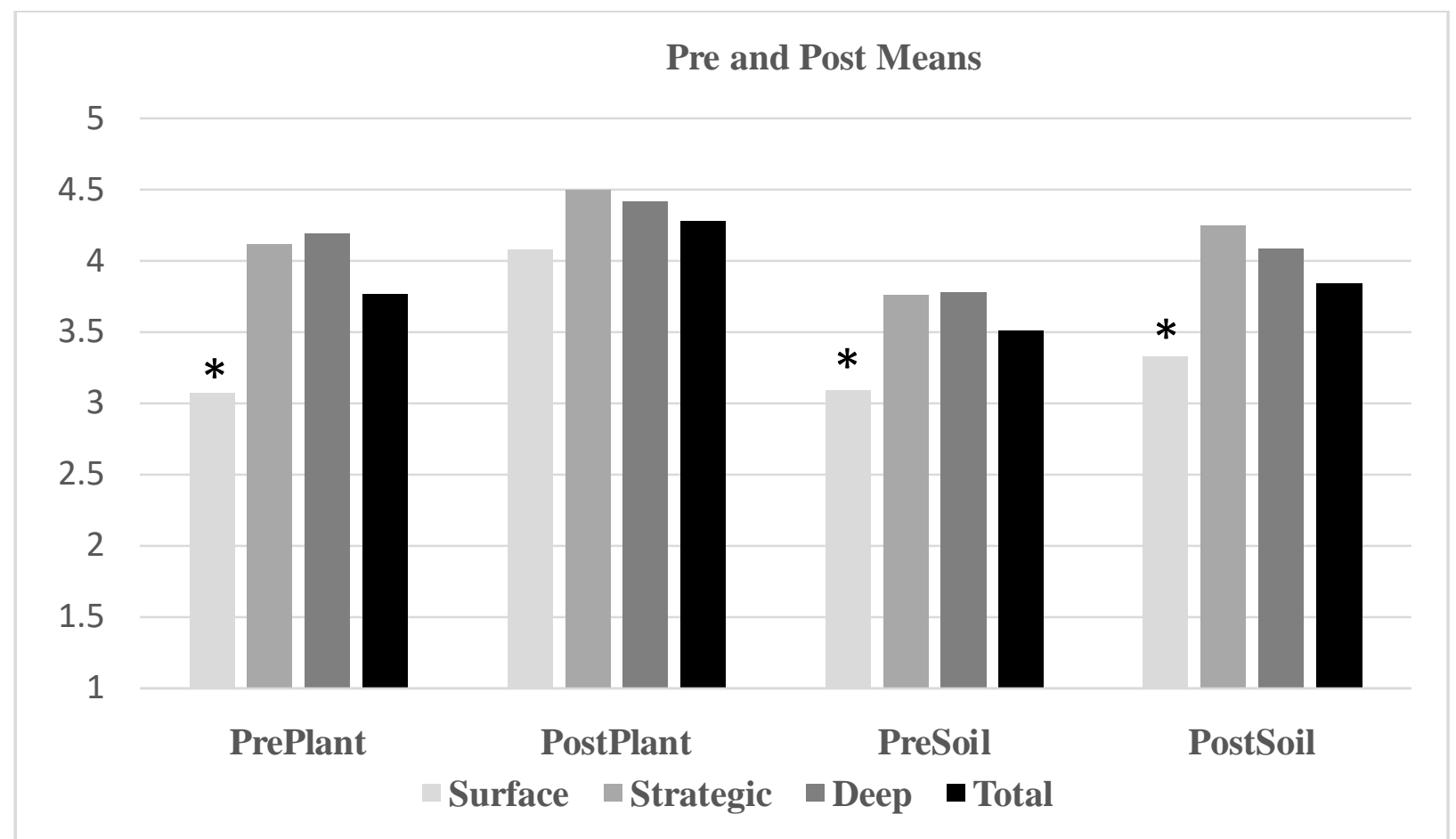

Figure 2: Mean score of student response to the statement "I enjoy the process of planning and conducting a scientific experiment designed to test a hypothesis." At the start and completion of the Plant Science 131 and Soil Management 269 courses for the three learning style grouping in each course.

$Y$ axis score 5 strongly agree to 1 strongly disagree. The three learning style groups and means of the total number of participants in Plant Science 131 (Plant) and Soil Management 269 (Soil). The symbol * designates response that were significantly different at the 0.05 level between the learning style 


\section{Pre and Post Means}

\section{5}

4.5

4

3.5

3

2.5

2

1.5

1

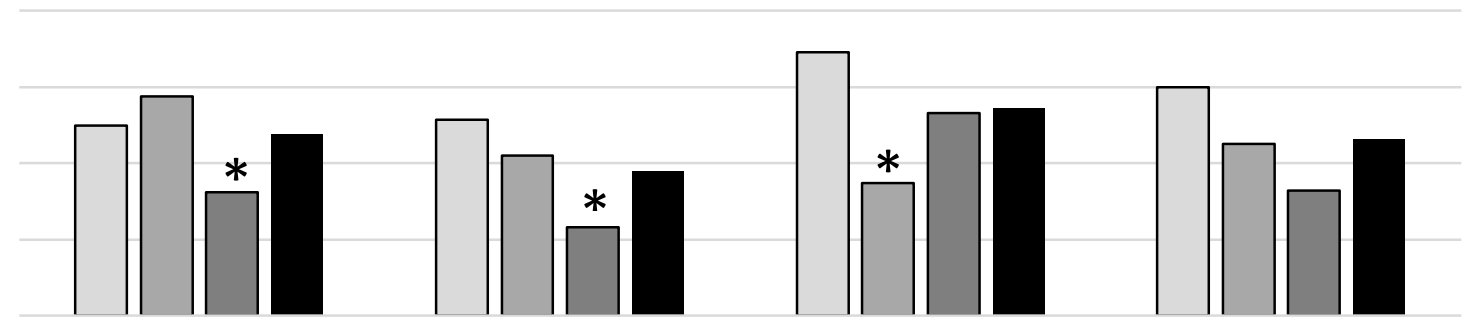

PrePlant

\section{PostPlant}

PreSoil

$\square$ Surface $\square$ Strategic $\square$ Deep $\square$ Total

PostSoil

Figure 3: Mean score of student response to the statement "The writing and sharing of peer-reviewed and published scientific reports is less important now than it was decades ago." At the start and completion of the Plant Science 131 and Soil Management 269 courses for the tree learning style groups in each course.

$Y$ axis score 5 strongly agree to 1 strongly disagree. The three, learning style groups and means of the total number of participants in Plant Science 131 (Plant) and Soil Management 269 (Soil). The symbol * designates response that were significantly different at the 0.05 level between the learning style

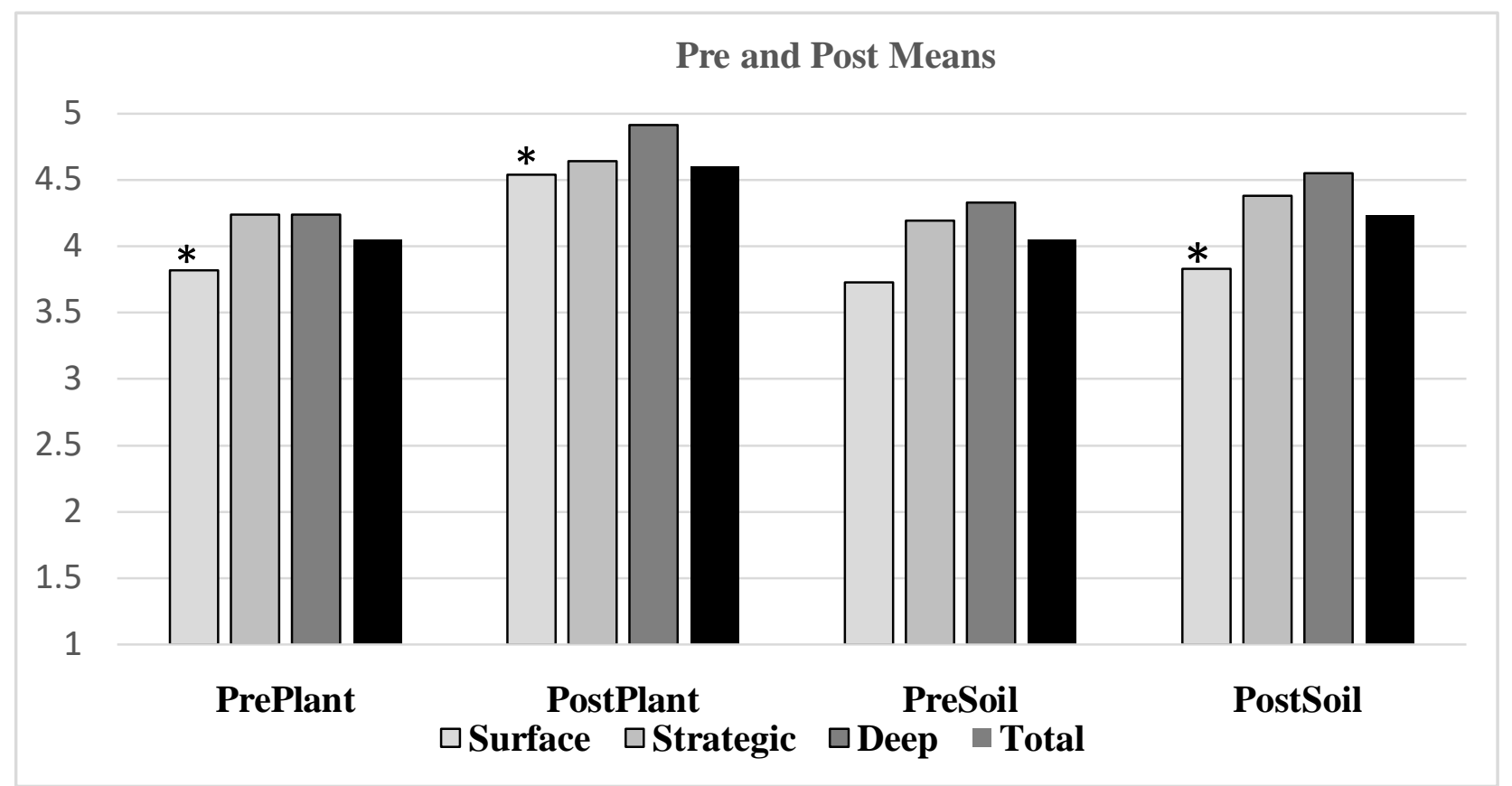

Figure 4: Mean score of student response to the statement "I understand the value that peer-reviewed and published scientific reports have in society." At the start and completion of the Plant Science 131 and Soil Management 269 courses for the tree learning style groups in each course.

$X$ axis score 5 strongly agree to 1 strongly disagree. The three, learning style groups and means of the total number of participants in Plant Science 131 (Plant) and Soil Management 269 (Soil). The symbol * designates response that were significantly different at the 0.05 level between the learning style. 